\title{
Isolation and detection of reovirus from arthritis in chickens
}

\author{
S.Y. Al-Baroodi \\ Department of Microbiology, College of Veterinary Medicine, University of Mosul, Mosul, Iraq \\ Email: Safwanalbaroodi@yahoo.com
}

(Received April 4, 2019; Accepted July 6, 2019)

\begin{abstract}
In this study 70 samples were collected from 14-26 weeks old egg laying hens. Clinical signs of infected chickens characterized by lameness, swelling in hock joint. Samples include blood for preparation of serum also hock joints and tendon for virus isolation. Hyperimmune sera was prepared by injection of broiler chickens four times with vaccine strain Reo $1133^{\mathrm{R}}$ $0.2 \mathrm{ml}$ subcutaneously in the neck. Samples were processed and prepared for virus isolation by using 6 days old embryonated chicken egg which was inoculated in yolk sac four passages. Lesions in egg embryo was recorded for each passage then the isolates were diagnosed by using neutralization test using convalescent and hyperimmune sera. Clinical signs of infected birds characterized by swelling and enlargement and edema of hock joint, postmortem lesions revealed swelling and injury in tendon, ulceration and erosions in cartilage and discoloration in synovial fluid, hemorrhage in the leg and yellow necrotic foci in the liver, the result of virus cultivation in embryonated chicken egg show dwarfism in growth, death of embryo with subcutaneous hemorrhage, initiated in $2^{\text {nd }}$ passage and subsequent passages, this lesion increase in severity with progress of passages and with decrease in death time in hours and increase in titer of virus particles. The virus titer was decreased when neutralized by using neutralization test it gives 22 isolates were positive from 34 isolates.
\end{abstract}

Keywords: Avian Reo virus, Embryonated chicken eggs, Arthritis, Neutralization test Available online at http://www.vetmedmosul.com, (C) 2020, College of Veterinary Medicine, University of Mosul. This is an open access article under the CC BY 4.0 license (http://creativecommons.org/licenses/by/4.0/).

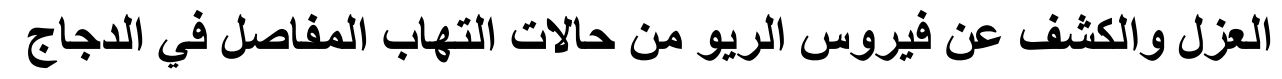

$$
\text { فرع الأحياء المجهرية، كلية الطب البيطري، جامعة الموصل، الموصل، العراق البارودي }
$$

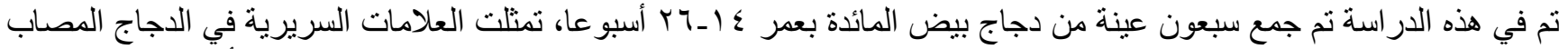

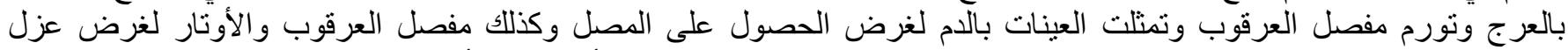

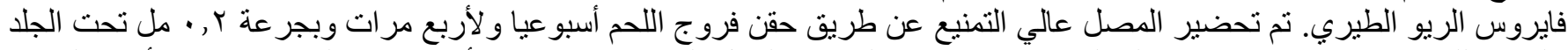

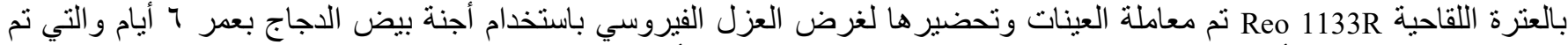

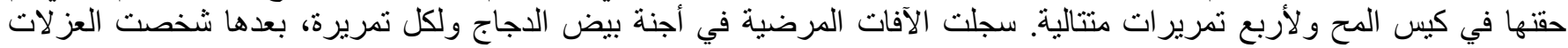

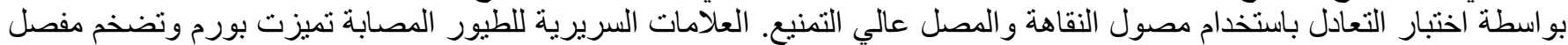

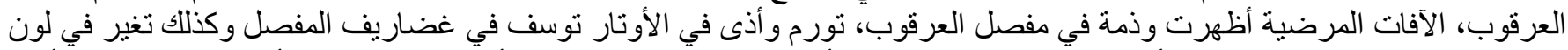

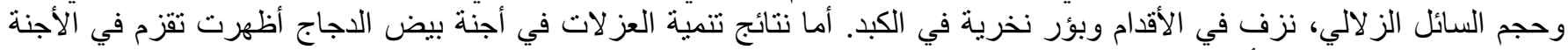

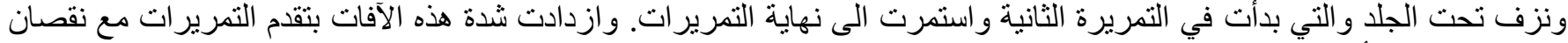

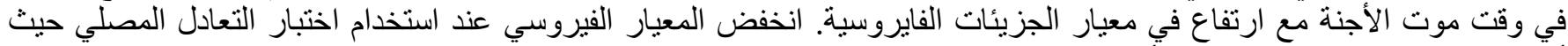

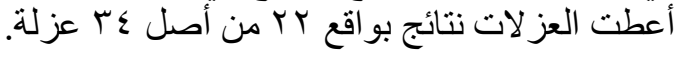




\section{Introduction}

Avian Reovirus (ARVs) belongs to the family Reoviridae, these viruses possess nucleic acid (Double strand RNA) ARVs particle can be range between 70-80 nanometer, the virus infect many types of birds (1), causing variant degrees of clinical signs represented in tenosynovitis, with post mortem changes characterized by edema and swelling in hock joint with lameness, sometimes the lesion developed causing rupture in gastrocnemius tendon with ulceration cartilage this signs combined with other signs including bleeding in legs which showed bluish to green in color, the virus infect chicks 4 weeks old and the morbidity rate reach $10 \%$, while mortality rate is lesser (2), the ARV cause hepatitis, myocarditis, pericarditis, respiratory and gastrointestinal tracts infection in addition the virus cause malabsorption syndrome with immunosuppression and autoimmunity (3). The virus replicates initially in small intestine and bursa of Fabricius then spread after 24-48 hours to another organs. subclinical infection is the main characteristics of reovirus. This character gives the secondary infection to stimulate the latent infection to reactivate infection and interact with other bacterial and viral etiological agents, in addition reovirus like other immune suppressor viruses as avian adenovirus type 4 which cause immune suppression and failure of vaccination program $(4,5)$. The virus spread horizontally and vertically, newly hatched chicks exposed to infection if our breeders is not vaccinated, chick shed the virus through oral and cloacal, through the contaminated foot pad injuries in addition through respiratory and gastrointestinal tracts. The vertical transmission is characterized by death in embryonated chicken eggs and decrease the percentage of hatchability (6). The ARV is able to grow in many types of cell culture lines as Vero cell, chick embryo fibroblast, chick embryo lung. In addition, the virus is capable of growing in 6 days old embryonated chicken eggs if inoculated in yolk sac causing embryo death after 72-96 hours of inoculation the embryo shows yellow necrotic lesions in the liver (7). The virus was also diagnosed through the detection of virus antigens by using agar gel diffusion, direct fluorescent with presence of specific antibodies. moreover, the virus can be diagnosed by using molecular technique as RT PCR (8).

Due to the importance of this virus and its disease and the effects in the poultry industry, economic losses and no previous study were conducted in Iraq to isolate the virus, so this study was performed.

\section{Materials and methods}

\section{Sample collection}

Total of seventy samples (hock joints, tendon and blood) were collected from egg laying hens at 14-28 weeks old in Nineveh province. These chickens suffered from lameness, swelling of hock joints. The blood samples were collected, then serum was separated and stored in $-20{ }^{\circ} \mathrm{C}$ $(9,10)$.

\section{Preparation of hyperimmune serum}

Non vaccinated broiler chicks breeds were vaccinated at 4 weeks age with reovirus vaccine (Intervet vaccine Nobilis Reo $1133^{\mathrm{R}}$, $\log 10^{3.1} \mathrm{TCID}_{50}$ ) weekly for four weeks intervals, the dose of vaccine was $0.2 \mathrm{ml}$ subcutaneous. Blood collected from vaccinated broilers and the serum separated and stored $-20^{\circ} \mathrm{C}(10)$.

\section{Preparations of samples}

Samples was taken 1 gram of cartilage and tendon cut and grinded it in sterile mortar using sterile pestle and sterile sand then added phosphate buffer saline (3). The granted organ put it in test tube, centrifuged $2500 \mathrm{rpm} 4{ }^{\circ} \mathrm{C}$ for 10 minutes, the sediment discard and the supernatant added to penicillin $10000 \mathrm{IU}$ per $1 \mathrm{ml}$ and streptomycin $10 \mathrm{mg} / 1 \mathrm{mil}$ then stored $-20^{\circ} \mathrm{C}$.

\section{Isolation of ARVs}

Virus was isolated by using 6 days chicken embryonated eggs (CEE) with no history of using reovirus vaccine were inoculated with $0.2 \mathrm{ml}$ of supernatant in yolk sac, the eggs were incubated in $37{ }^{\circ} \mathrm{C}$ and daily candling and recorded the death time of embryo, lesions and virus titrations then after 5 days of inoculation the yolk was harvested and returned inoculation 4 passages (11).

\section{Diagnosis of virus isolates using neutralization test}

For diagnosis, the virus isolates were six double diluted, then equal volume of convalescent serum and hyperimmune sera separately were added to each dilution, incubated $37^{\circ} \mathrm{C}$ for 1 hour, the vaccine strain considered as positive control, then inoculated for each dilution in yolk sac of embryonated chicken eggs 6 days old (10 embryo for each dilution) then examined daily, the virus titer measure according to Reed and Munech (13).

\section{Results}

\section{Result of clinical signs and post mortem examination}

The result of clinical signs of infected chicken show lameness and swelling in hock joints, edema, sometimes rupture in gastrocnemius tendon, post mortem examination lesion revealed hemorrhage in legs with bluish to green in color, erosions in cartilage with change in the color of synovial fluid (Figure 1-3). 


\section{Result of virus isolation and propagation in chicken embryo}

The result shows no lesions was recorded in $1^{\text {st }}$ passage, then $2^{\text {nd }}$ and subsequent passage revealed lesions which include petechial hemorrhage under the skin, dead of embryo with dwarfism, these lesions increase in severity in the later passages with decrease in embryo death time and increase of virus titer (Figures 4-6) (Table 1).

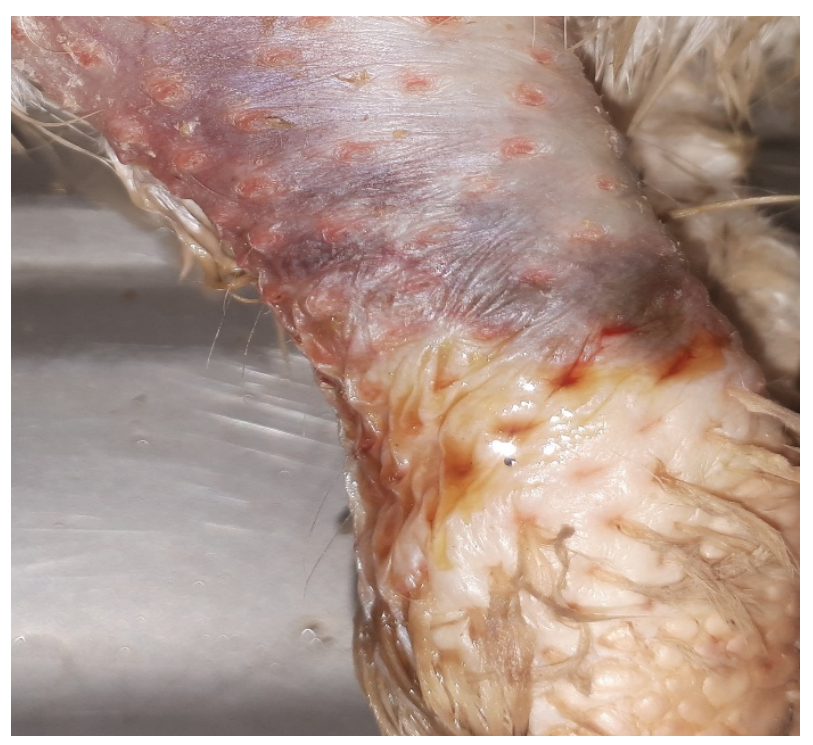

Figure 1: A 20 weeks old egg laying hens showing edema and hemorrhage in the leg.

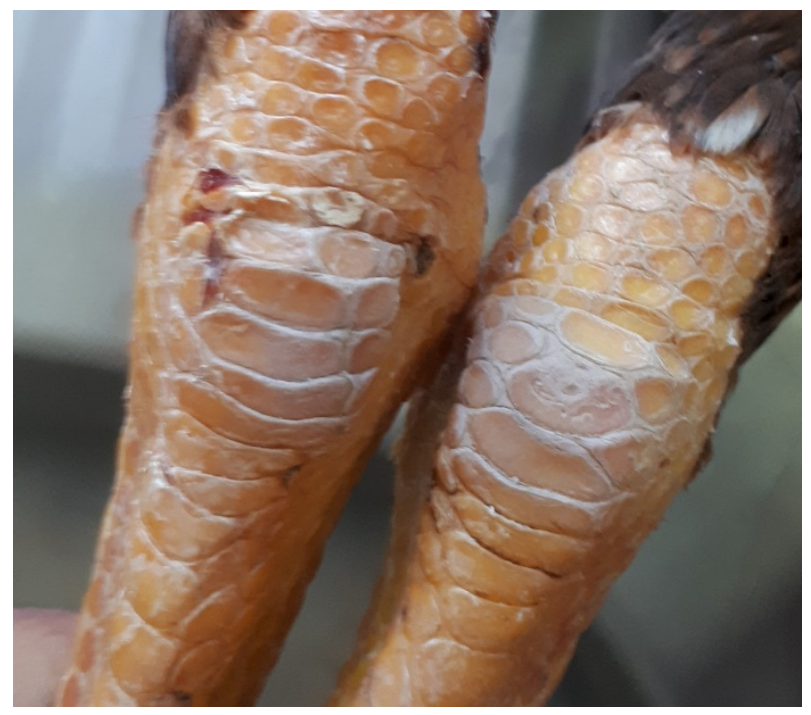

Figure 2: A 26 weeks old egg laying hens showing swelling and edema in hock joint.

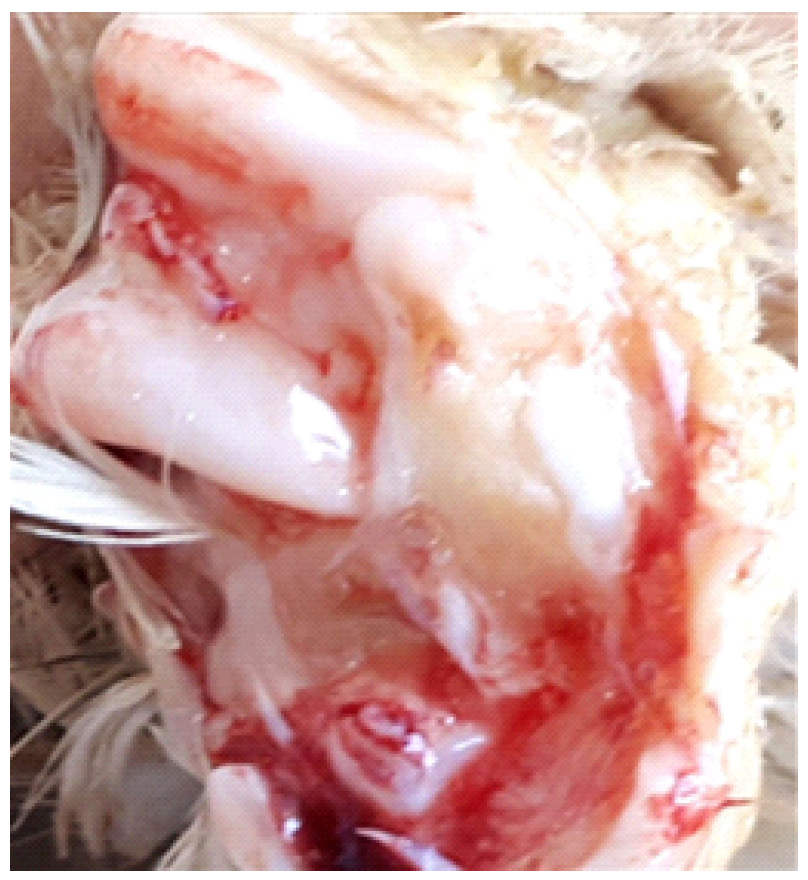

Figure 3: A 33 weeks old egg laying hens showing increase the volume and change in color of synovial fluid of hock joint.

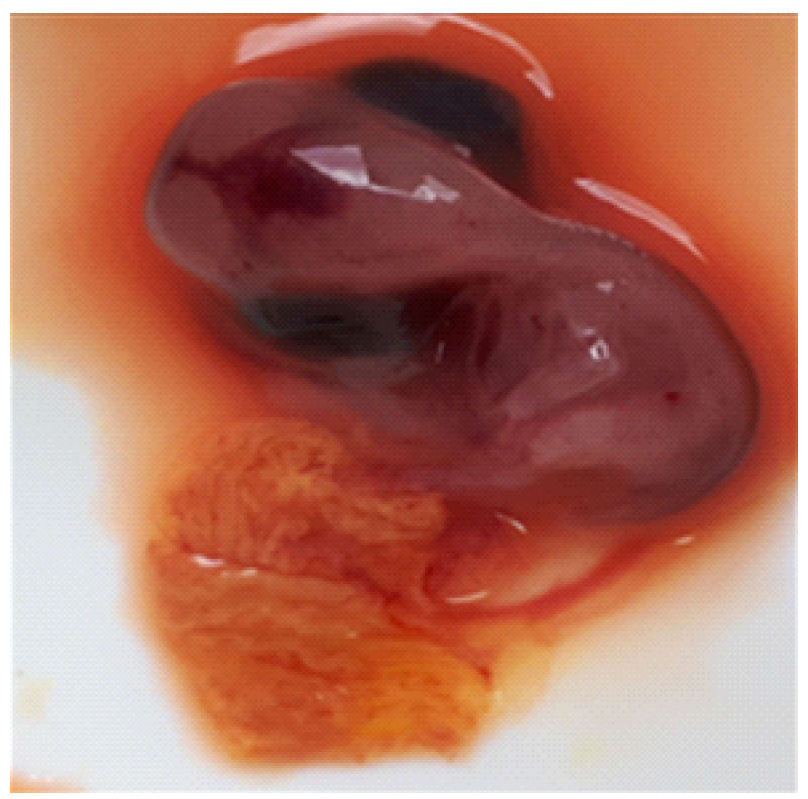

Figure 4: Chicken embryo in $4^{\text {th }}$ passage showing hemorrhage in head. 


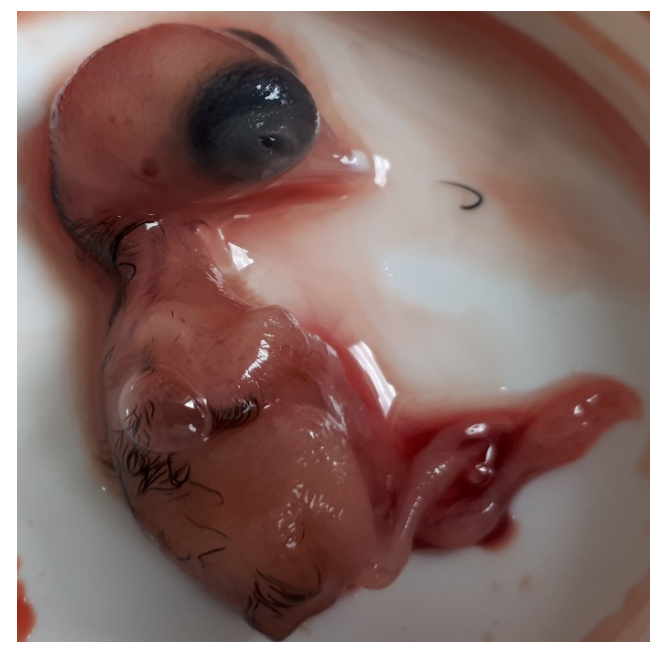

Figure 5: Chicken embryo in $4^{\text {th }}$ passage showing dwarfism retardation of growth.

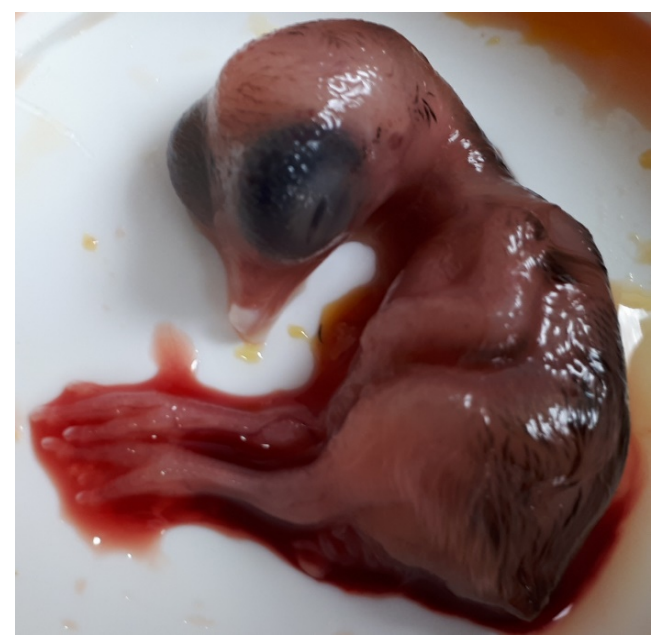

Figure 6: Chicken embryo from control group.
Table 1: Result of virus isolation and propagation in chicken embryo

\begin{tabular}{lcccc}
\hline Passages & P4 & P3 & P2 & P1 \\
\hline Mean titer of isolates & $10^{3.2}$ & $10^{2.4}$ & $10^{1.9}$ & $10^{1.2}$ \\
EID50/0.1ml & & 72 & 96 & - \\
Time of death (hours) & 72 & 72 & ++ & - \\
Dwarfism & ++ & +++ & ++ \\
Hemorrhage & +++ & +++ & ++ & - \\
Edema & +++ & +++ & ++ & + \\
\hline
\end{tabular}

This score is representing the severity of lesions, (-) no lesions, $(+)$ mild lesions, $(++)$ moderate lesions, $(+++)$ sever lesions

\section{Diagnosis of isolates using Neutralization test}

Result of neutralization test show that the titer of virus isolates decreases when processed with convalescent serum and hyper immune serum. It gives positive result 22 from 34 isolates which can be perversely propagated in embryonated chicken eggs (Table 2).

\section{Discussion}

ARVs is one of the effective viruses of poultry industry which cause severe economic losses because it infects respiratory and gastrointestinal tracts in addition to arthritis, this virus is difficult to diagnose clinically or by post mortem examination because these signs interact with some others viral and bacterial infection (14). This virus cause arthritis in chicken which is the most common, so this study focused on these signs and collected the samples from it never than other organs. The samples were collected after post mortem done which is suspected from reovirus infection. The chickens were suffering from arthritis in addition to lesions in the liver, when comparison those signs with standard experimental infection with Reo virus which can match the result of Ballal et al (15) from the experimental study in chicken by virus isolates.

Table 2: Result of neutralization test

\begin{tabular}{lcc}
\hline Type of virus treatment & $\mathrm{N}^{\circ}$ of positive isolates & Titer \\
\hline Mean of virus isolate titer before process EID $\mathbf{5 0 / 0 . 1 \mathrm { ml }}$ & 34 isolates & $10^{3.2}$ \\
Mean of virus isolate titer after process with convalescent serum EID $\mathbf{5 0 / 0 . 1 \mathrm { ml }}$ & $22 / 34$ Positive & $10^{1.1}$ \\
Mean of virus isolate titer after process with hyperimmune serum EID $50 / 0.1 \mathrm{ml}$ & $22 / 34$ positive & $10^{2.4}$ \\
\hline
\end{tabular}

The result of propagation of samples in embryonated chicken eggs show cytopathic Effects in embryo which manifested by hemorrhage and edema in embryo those result similar to Ballal et al (15) Natalia and Hanna (16) in severity, the result in this study show hemorrhage in visceral of embryo with necrotic lesions in liver, the reason of differences in severity of lesion to the fact that differences in virulence between the viral strains which causes severe lesion in both chickens and embryos. The severity of lesions in embryo increase with progress of passages accompanying death in embryo with dwarfism, which seriously with increase the virus particles. Those lesions are not recognized in $1^{\text {st }}$ passage, the reason of that is due to titer of the virus particles which increase with progresses of passages (18). 
The virus isolates were diagnosed by neutralization test which give real picture to viability of virus in cultivation host. The result show decrease in the titer of virus isolates when processed with convalescent serum and hyperimmune sera. The reason of that is to be accustomed to adduce by Wickramasinghe et al (19) the reason of variation due to several reasons firstly the variation in the antigenicity of viral strain which can be used in neutralization test and the strains which induce the infection in field. This reason causes decrease in positive samples in neutralization test, although this negative strain induces CPE in chicken embryo and pathognomic clinical signs in infected chickens, this corresponds with mentioned Rafael (2) the time of collection of samples attempted in the acute phase of infection and appearance of clinical signs. This induce increase of virus particles in samples, Lobani et al (20) said that the severity of infection in adult chickens is more than the young ones.

\section{Conclusion}

This study concluded that these viruses are severely affected poultry industry in Iraq.

\section{Acknowledgment}

The authors wish to thank the College of Veterinary Medicine/ University of Mosul for financially supporting this work.

\section{References}

1. Judith MA, Ruth M, Guntram P, Marja JL, Gerry M. Reovirus infections associated with high mortality in Psittaciformes in the Netherlands. Avi Pathol. 2007;36(4):293-299. DOI: 10.1080/03079450701447309

2. Rafael AB. Pathogenicity of variant field isolates of avian reovirus and molecular characterization of Brazilian variants from commercial broilers [MSc thesis]. Brazil: University of Georgia; 2006. p.70-72 http://purl.galileo.usg.edu/uga_etd/bampi_rafael_a_201605_ms

3. Abd El-Samie LK. Some causes of chickens growth retardation Sharkia, Egypt. Assiut Vet Med J. 2015;61:144. https://www.researchgate.net/publication/316140072

4. Al-Attar MY, Danial FA, Al-Baroodi SY. Immuno-Suppressive effect of avian adenovirus infection of Newcastle disease vaccine efficacy in broiler. Iraqi J Vet Sci. 2004;18(1):39-44. https://scholar.google.com/citations?user=korNIoIAAAAJ\&hl=a

5. Antarasena C, Promkuntod N, Prommuang P, Tongwongsa L, Prommung $\mathrm{P}$, Anant S. Isolation of avian reovirus associated with sudden death in laying chickens and antibody response of Newcastle disease virus vaccination. $11^{\text {th }}$ International Symposium of the World Association of Veterinary Laboratory Diagnostic and OIE. Seminar on biotechnology. 2003; 9-13. https://www.researchgate.net/ publication/257299124_Avian_reovirus_infection_associated_with_su dden_death_in_laying_chickens_and_transient_immune_suppression_ to newcastle disease virus vaccination

6. Al-Muffarej SI, Carol ES, Jones RC. Egg transmission of avian reoviruses in chickens: Comparison of a trypsin sensitive and a trypsin-resistant strain, Avi Pathol. 1996;25(3):469-480. DOI: 10.1080/03079459608419156

7. Elmubarak SAM, Kheir AI. Occurrence of runting and stunting syndrome in broiler chicken in Sudan. Revue Elve Med Vet Pays Trop. https://www.ncbi.nlm.nih.gov/pubmed/1966397

8. Hedayati M, Shoojadost B, Peighambari SM, Ghalyanchi L. Characterization of reoviruses isolated from some broiler breeder flocks in Iran. Arch Razi Inst. 2016;71(4):227-234. Doi:10.22034/ARI.2016.107507

9. Rai A. Methods in veterinary virology. Indian Vet Res Inst. 2005;1:50-52. http://ivri.nic.in/division/ah/biotech/Scientist Details.aspx?ID=16

10. Rai A. Laboratory manual of cell culture and animal virology. Indian Vet Res Inst. 2008;10:8-12. http://ivri.nic.in/division/ah/biotech /ScientistDetails.aspx?ID=16

11. Jones RC. Avian reovirus infections. Rev SciTech Off Int Epiz. 2000;19(2):614-625. DOI: 10.20506/rst.19.2.1237

12. Erica S, Mary PJ, Holly S. The pathogenesis of turkey origin reoviruses in turkeys and chickens. Avi Pathol. 2005;34(4):291-296. DOI: $10.1080 / 03079450500178501$

13. Reed LJ, Munech H. A simple method of estimating fifty percent end point. Am J Hyg. 1938;27(3):493-494. https://academic.oup.com/aje/ article-abstract/27/3/493/99616

14. Eric G. An Epidemiological investigation of avian reovirus among commercial broiler chicken flocks in Ontario [MSc thesis]. Canada: University of Guelph; $2013 . \quad$ P:14-16. https://pdfs.semanticscholar.org/fa50/f6005ffb8272440766b50c0f0db 2f509acb6.pdf

15. Ballal A, Kheir SA, Amal MA. Reovirus associated with tenosynovitis and rupture gastrocnemius tendons in chickens. Sudan J Vet Res. 1998;15:1-6. http://www.sudanjvr.net/journal/1592.pdf

16. Natalia WK, Hanna C. Detection of avian reovirus in wild birds in Poland. J Vet Res. 2017;61:239-245. https://www.ncbi.nlm.nih.gov/ pmc/articles/PMC5894429/

17. Guneratne JRM, Jones RC, Georgiou K. Some observations on the isolation and cultivation of avian reoviruses. Avi Pathol. 1982;11(3):453-462. https://doi.org/10.1080/03079458208436117

18. Nalyvayko L, Parkhomenko L, Nikolaienko Y, Pankova O. Poultry Reovirus infection and development of its specific prevention in hens. J Vet Med Biotechnol Biosafety. 2017;3(2):19-25. http://jvmbbs.kharkov.ua/archive/2017/volume3/issue2/oJVMBBS_20 17032_019-025.pdf

19. Wickramasinghe R, Meanger J, Enriquez C, Wilcox GE. Avian reovirus proteins associated with neutralization of virus infectivity. Virol. 1993;194(2):688-696. DOI: 10.1006/viro.1993.1309

20. Lobani AM, Charaibeh SM, Al-Majali AM. Relationship between different enteric viral infections and the occurrence of diarrhea in broiler flocks in Jordan. Poult Sci.2016;95:1257-1261. DOI: $10.3382 / \mathrm{ps} /$ pew054 